\title{
Utilising networks in the field of school librarianship.
}

\section{The librarian and the relationships and networks that they NEED.}

\author{
Amanda Jane Gough \\ Librarian \\ Kellett International School \\ Hong Kong
}

We are all aware how isolating the role of a school librarian can be. In this paper I will discuss how we can build and cultivate networks both within and outside school to form a harmonious environment that will ensure that encouraging the reader is first most in our minds. I will discuss how some networks have worked in one situation and if it is possible to make the networks work in all situations?

Having worked in the field of both school and public librarianship over a period of 12 years I feel my work has covered a wide variety of areas. My 4 posts have been extremely dissimilar and have led me to work with a great number of different groups. Although predominately I have worked in the field of school librarianship the schools have been tremendously different which has led me to develop the diverse networks to aid me in my job.

I see Reading as The most important part of my job. Within the schools and public libraries I have worked with I have experienced many different views towards readers and reading. I'm sure we have all read reports that state that exams are getting easier - we are dumbing down, children don't read, boys don't read, however in the 12 years I have been working with children and adults I can't say I have noticed this to be the case.

Within my four working environments I have used one or more of the following networks: teachers; parents; school librarians; other librarians and outside agencies. I have developed over my career these working partners and have found them to be of great use, sometimes frequently or rarely. It has been my experience that fellow librarians in particular are always on hand to assist a colleague in any way they can.

It is true to say school librarians in particular are often solitary workers, although many in high school libraries may have pupil librarians/monitors it is my observation that many schools employ a sole librarian unless they are an extremely large institution that requires more than one member of staff. I have, within my 12 years of working in schools met many school librarians and with the exception of job shares, where two librarians work in the same post (splitting the working week in any number of ways) I have met just a handful of school librarians who have library assistants either full or part time. Maybe it is this reason that we cultivate and cherish the networks we build, as human beings we are not by nature solitary creatures. 
All schools are different, although their aim is the same - to educate the child. We all know even from our own experiences that each educational establishment has its own idiosyncrasies. Having had a main stream education (that is to say government, and mainstream for the area I lived in), and having worked in two urban secondary school, a dual use library and an International primary school library I can say we are all essentially the same BUT different!

\section{High School teachers}

There is no denying that some teachers spend more time with the pupil and can help guide the child into various areas of literature, but it is the librarian with his/her broad knowledge of the current literature which is invaluable to both the teacher and the child. In high schools the librarian is often closely linked, not surprisingly with the English department. Usually a working partnership develops between the head of English, the English class teachers and the librarian. Whether or not each class or English group visit the library is dependant on the individual schools' curriculum. My experiences here have been varied.

The first school I worked in I worked with the head of English and devised a programme of library lessons for every English class in school. These varied depending on year groups. Lower school, Years 7 and 8 would visit the library on a weekly basis and follow a set programme of lessons devised by myself with the assistance of the English department. Together this group would ensure that reading in the library was the focus of the sessions where we all believed that to access the other subjects the children needed a solid reading foundation. As we are all aware children are all individuals so flexibility had to be built into the programme to ensure each child would be able to complete the work whilst still gaining reading experience in a variety of ways. This programme we named Read Around Salford. After the initial usual library lessons of orientation the children would all get their own individual reading booklets which they were allowed to complete in any way they wished. The variety of reading within the booklet allowed children to read non-fiction; newspapers; magazines and novels under a variety of genres. Mixing the styles of reading and allowing the children to undertake the reading in their own time and in their own way gave the children a sense of ownership of their own learning. Of course their were cases when children were not reading their favourite style of writing however they occasionally discovered a new style of literature, a new author to read or they learnt who or what to avoid in the future in their reading. The older pupils followed a different format of lessons, theirs was mainly information skill based and my involvement with upper school as readers was in a purely informal way. Still including teachers, both in the English department and other subjects we would discuss classes and pupils and their reading habits. I was always made aware via pastoral meetings with teachers of ways to involve reluctant readers and when to halp a reader deal with an issue via the book i.e: anorexia, vegetarianism or illnesses.

My second school was similar to my first. I strongly worked with the English department and more unusually humanities and science. It was the science and 
humanities departments that often used the library for research and topic work, therefore it is in these areas I saw pupils and introduced a number of different things they may want to read. Seeing a connection to what the pupils enjoyed doing in their topic work inspired them in their reading choices. Similarly to my first school the lower school of Years 7 and 8 had regular library lessons. Although not as structured as my first school I developed a competitive streak within the year 7 and 8 tutor groups which ensured reading became a game every wanted to win. I kept records of books read by each group and on a weekly basis I would publish the results. The tutor group teachers would all be eager to have the group who read the most. This developed a school that prior to my arrival had had no library - to a school with a strong and healthy reading philosophy.

The third high school I worked in was the one I experienced the most change. Here I was as a dual use librarian. This strange title relates to a librarian who works in a dual use library - merely a library with two uses. In this case the community library also served as the school library for the High school which it was attached to. As a high school librarian I was geographically more isolated than in my other schools. Classes had not regularly used the library with the exception of initial library orientation classes for Year 7. I over time developed links with teachers from different departments and it is this network which then established groups from many different subjects into the library. Pupils from many different year groups visited the library with a variety of subject teachers: Design and Technology; history; drama; music; tourism and English. It was my idea to try and create a reading and information skills programme through PHSE (Personal Health and Social Education), however the limitations of the school timetable and the library meant that this was not possible. It was through the community role I was able to reach the readers within the school, library programmes such as the summer reading challenges ensured a reading momentum from primary school and at the end of the pupils first year at high school, for some pupils it was enough of a boost they needed to become a life long reader. They would then become regular readers and visit the library at lunchtimes and after school once they had got the reading habit.

\section{Primary School teachers}

During my role as a dual use librarian wearing my community librarian hat I worked with class teachers for children from Reception/Kindergarten age to primary 6 teachers. With the work I did I expanded my area of expertise within the area of Children's literature and I think it may have been here I developed my love of The Picture Book. Although I had used picture books in the high schools I had previously worked in, they naturally had only a small selection of this type of book. Visiting primary schools and nurseries and having these groups visit the library allowed my new love of The Picture Book to develop. Reading to younger children and discovering their enthusiasm for reading gave me as a school librarian a new enthusiasm for reading myself. This enthusiasm was then transmitted to the older children I had contact with as we discovered old favourites, new authors and the world of picture books for older readers - these books were of great interest to lower ability pupils. In the library we often see 'weaker children' 'outsiders' and these are in many cases children who are less able. During lunchtime sessions I would introduce picture books for older readers such 
as The Man by Raymond Briggs, Willy the wimp by Anthony Browne, puzzle and maze books and these children would then show others and the books became their way of making friends. In hindsight I am sure I could have expanded the links with primary school teachers that I developed. Especially with reference to expanding my knowledge of children's author for younger children, working predominately in the secondary area I had a vast knowledge of books for that age group but only a passing knowledge of books for much younger children which I now firmly believe are ideal for reluctant readers.

My current role is as a primary school librarian. This is the most reading rich environment I have been exposed to. The pupils all visit the library at least once a week I have constant contact with KS2 pupils (aged from 7-11) which I truly enjoy. I adore helping these children find the right book for them, whether it is a new author for a child just starting out on 'chapter books' or an author who has been writing for many years. The primary teachers I now network with are within my own school. We discuss reading and pupil performance either with the pupil during a library session or at any other mutually convenient time to discus the books that the child will enjoy but s/he can read confidently and be challenged when it is needed. As we all have our favourite authors, genres etc. teachers are the same and it important that we as mediators and experts can ensure the pupils in any particular class do read a great deal of variety. I am sure that many of us know of a colleague we have worked with who will always recommend "The Classics.”

It is important to build the network of primary teacher and school librarian. The teachers are the ones who know the child best, their abilities, interests etc and it is working closely together that the team of teacher and librarian can be a unit able to provide books to stimulate excite and appeal the child.

\section{Parents}

Within my role as the librarian of an International school in Hong I am fortunate enough to have a strong network of support from parents. I have a 20 strong band of volunteers who work with me regularly in the library. During these times we discuss current reading trends, the 'right age' for the 'right book' and the common errors parents and others make when selecting books for their children. Through teachers, parents and with the individual pupil in mind it is an achievable feat to encourage reading both in school and at home at the appropriate level. We can encourage, challenge and make reading a pleasure with the team of home and school, working together. There are a variety of ways to involve parents and create a network. Many schools have a homeschool diary, using the diary as a communication tool parents can discuss reading and any other aspect of work with the teacher and the librarian. I am personally against book lists, they are great for children who want to find authors who write similarly or for pupils who want guiding with their reading, however I have found if I create a book list some parents will insist that their child reads everything on the list and this I feel is not always a constructive way to view reading - each child is an individual and we therefore cannot create a definitive list of books - that should be read however we can always recommend books and hope these choices are explored by the parent and the child. 
In the past if I needed to contact parents, the quickest way to communicate was either by telephone or by letter. Today it is possible to reach a great number of people via e-mail. A system my current school uses is a class e-mail system. Each class is assigned a parent whose job it is to contact the rest of the class to let them have any information they need to know. This is both quick and efficient. I may need to let the parents know about an upcoming event (usually this is a reminder of something they have been told early in a newsletter); or I may be letting them know about a visiting speaker or about a new bookshop that they may be interested in or about a book sale. Via e-mail I can reach every parent in school very quickly and on the whole parents respond well to the information. Information can also be communicated by the school newsletter. These are often a regular bulletin and I have used them to report about past events, forthcoming events and literary aspects of the school library - ie: our library policy or if there is a change in anything.

Another important event to the librarian is the literacy evening. Currently I have been able to talk to parents at a foundation stage (Kindergarten) literacy evening, this is for parents of our 3-4 year pupils, and I am hoping that between me, the parents and the literacy coordinator in school we can put together more literacy events to discuss school reading policies and the importance and pleasure of reading.

With the assistance of parent helpers and with the parent network I have developed an open door policy both before and after school; I feel it is important to allow parents to choose books from the library to read to and with their child. It is also important for the parents to see the choices their children have when they themselves visit the library. I often chat to parents about my decisions with regard reading books and topic books, also they are interested to know why their child was 'made' to take home an information book or poetry books when they have no interest in this area, it is simply a matter of balance and ensuring the child is exposed to different styles of writing and different books.

One of the things I appreciate from the parent network is the discussion about books they read as children. Working in an International school means I see parents from many different countries; we currently have children in our school from 22 different nationalities. Their parents have had a wide range of different literary experiences and I appreciate them sharing with me their favourite authors, many of whom I have yet to discover. These add to the library and ensure we have a truly international library that reflects the school family. Of course we have a school Website and it via this that parents can also learn about aspects of the school including the library. It is my duty to ensure the web page is up to date and of interest to the parents with relevant information, although sometimes this is a repeat of information already disseminated it is useful to have a record that the parents and children can access.

My current role has led me to utilise the parent network. I have considered if I could have used such a network in my previous jobs. It is possible with todays' technology that email and websites ensure communication is easier than before and if a network could be created in a first assistance via a welcome meeting or via another voice 
would a parent network be useful? Sometimes we depend upon the pupils of high schools to pass on information about school to their parents, maybe we as information providers also need to consider other means of getting parents involved and informed. I maybe wrong in my assumption but I know from my own experiences and those of my fellow high school librarians parent networks haven't been used, maybe it is time to change this? Having had a successful parent network which I have found extremely useful I would definitely be open to the opportunity in my next high school role.

\section{Public librarians}

In my four posts I have created networks on two occasions. In my second job the geographic closeness of a local public library enabled me to work with the local library service. After initial communication pupils librarians from my school assisted the local library in book selection. This task became to be seen as a great reward and sparked an interest in reading in the school where there had previously been no school library or interest in the local library. The resources and expertise of the local library also were helpful to me when I need assistance in book selection, choosing other types of information such as current CD-ROM's or databases.

My role as a dual use librarian involved me in the day to day running of a dual use library and 3 other branches. I was of course part of the local library service operations team and here I had access to a whole service of librarians. This network was highly supportive and I didn't need to go very far to gain help if I needed it. In addition to the daily running of the library the library assistants were of course extremely helpful in looking at new books, helping the pupils choose the right book and in spotting any ways I could entice pupils into the library. The high school pupil can be a reluctant reader, but with ideas from library staff we would come up with imaginative ways to make reading fun. With the assistance financially and in support the library staff helped me gain readers and ensure pupils were connected to the right book.

\section{School librarians}

The most important support and understanding I have as a school librarian has been from my fellow librarian colleagues. With each of the four school library posts I have held I have always been a member of the local schools library group. These have worked in various ways. My first posting was in Greater Manchester, UK. The high schools I worked in were very similar with a few exceptions. Many of the children we were working with came from disadvantaged backgrounds and the literacy levels were below average. The librarians in these schools were often battling to encourage children to read but the support we gave each other at our half termly meetings was invaluable. The meetings were always managed by the librarian from the local schools library service and her overall picture of the libraries helped us to deliver a quality even service.

My second post within a secondary school in a slightly less disadvantaged area also had a strong librarians group. We often had courses together run by the SLS and delivered our own training with each other at the half termly meetings. The most useful 
aspect of our meetings was their locations. We often met at one of the libraries and the host school would show us his/her library thoroughly, more than a quick glance s/he would demonstrate how classes would work, if they were computerized how this helped or hindered and what reading records they kept. Remembering that it is READING and books are the primary reason for our existence was always reiterated within these meetings with “best reads' or book suggestions. Magazine recommendations and controversial books were always on the agenda, to help librarians who were in a dilemma about what should or shouldn't be on the shelves, amongst ourselves we would not always agree and lively discussions would often ensue.

My third posting in the dual use library had the same strong school librarians' network I had come to expect and rely upon. Regular meetings held at different school libraries ensured we looked at different working environments and were able to share best practice. The discussion of books was always an agenda item along with promotion of the library the major focus of our work.

\section{ALESS}

My current role in an International school has brought with it fresh challenges to reading. I am now working with high achieving children who want to push reading boundaries and get ahead. In contrast I have many children who have English as a second language and require a different approach in looking for a book that will excite interest and challenge them. Initially I was contacted by a fellow school librarian to a monthly meeting of a group she termed ALESS (Association of Librarians in English Speaking Schools - HK). This group which was established in 2001. Of all the school library groups I have been involved with this group are the most dynamic. As technology has progressed greatly in the last couple of years when this group was being established they developed their group via the Internet. ALESS is a registered Yahoo group, the group has two elected coordinators and two list serve moderators who are elected at the May AGM. We meet every month except March when there is a literary festival in HK. The association also has an active list serve of which all members are encouraged to become full members. The role of the list serve is to facilitate communication between members for the sharing of ideas and resources. It is a closed list with membership by invitation only and all personal information remains within the list. Files are only available for ALESSHK members. I have found this group to be extremely supportive in every aspect of my work. Working in a new country and trying to understand all the small issues like - where to get book covering materials? Which local suppliers give the best discount? and how many book clubs are available? Although these are small things they are important to the day to day running of the school library and sometimes it is getting these things done quickly that enables us to attend to the important part of our job - enthusing children and teachers in their reading. This group have also been instrumental in establishing a reading competition which was brought to us by an American member of our group. The competition may not be a new one to those of you who have dealt with an American or Australian scheme; it is named Battle of the books. For those not familiar with the competition it is simply a way of encouraging children to read a wide variety of books the purpose of the Hong Kong Battle of the Books programme is to 
encourage reading by all pupils. Pupils, regardless of ability, are exposed to quality literature representing a variety of literary styles and viewpoints by prominent authors in the area of young adult literature. The game format creates interest and excitement in reading. Through the fun and excitement of the competition, students improve reading skills, mature in their choices of reading materials, and acquire a broader knowledge base. Even during the height of the competition, students and coaches should remember that the goal is to READ, not to win! Everyone who participates is a winner. The excitement this competition has generated within classes who although are avid readers sometimes lack enthusiasm for new or unfamiliar authors has ensured reading is foremost in our minds at all times.

\section{Unique Partnerships}

The most diverse role I ever had was as a dual use librarian. Wearing two hats, one as a school librarian and the other a community librarian I developed many diverse networks I ordinarily would not have developed had I not had this unusual role. As a Community librarian I worked with primary schools, community workers, museum staff and other community librarians, these strong networks aided me with my role as a deliverer of story and books to all ages. The position I had allowed me to investigate books for all ages from $0-99$. It was with the assistance of all the networks I had developed that I was able to match people with the right book, whether they were new readers, reluctant readers or those people who visit the library and insist they 'have read everything!' As I mentioned earlier I am a firm believer in steering clear of book lists for younger children however, I am in favour of them for more mature readers, they can be circulated amongst library staff and other networks to assist the reader who is struggling, for whatever reason in finding a book. My role included the most wonderful task reading books to very young children, with the aid of story sacks I was able to bring alive The Book. My network of primary teachers and local library staff enable the venture possible. Within my role as dual use librarian the most exciting part of my year was a week termed "Joint Week." This amazing week, which was usually themed, pulled every group in the community together. We had readings, lessons, visits and shows. It was one of the finest examples I have seen of a network of people working together to make things happen. Teachers from each of the feeder primaries, high school teachers, museum staff, recreation staff and myself worked together to put together a week of interesting, educational and fun activities that involved all schools in the 'cluster'. It was my task in that week to bring the library to the children and this I did by reading to as many children as possible - about 600, I think was the average number.

\section{$Y L G$}

Within my role as a community librarian I was elected onto the North West of England's YLG (Youth Library Committee), this mixed group of school librarians, public librarians and Children's services librarians met once a term to discuss many issues. The promotion of the Carnegie/Greenaway medal was always a hot topic and as many of us would discuss the maturity level of the books chosen. We would have a lively discussion 
and I always left the meetings with new knowledge of authors and fresh enthusiasm to pass onto the pupils I would meet the next day.

There are of course many one off partnerships which we as librarians create. During our work we may be in contact with a whole range of people and these can usually help us generate new ways to bring the child into the library and with the librarian ready introduce him or her into the magical world of reading. With enthusiasm the child/student can either be introduced to books or even in the case of an older pupil reintroduced to books as the marvellous objects they are.

\section{Author Note:}

Amanda Gough, has worked in a variety of school libraries over a period of 12 years. Having worked in the North West of the UK in public high school and a dual use library, she is currently working in a British primary international school in Hong Kong. She has belonged to many school librarian groups and is currently one of the coordinators of the ALESS group in Hong Kong. 
Reproduced with permission of the copyright owner. Further reproduction prohibited without permission. 